\title{
Pengajaran dan Pembelajaran di Era Digital
}

\author{
Nur Afif \\ Fakultas Tarbiyah, Institut PTIQ Jakarta, Indonesia \\ nur.afif86@gmail.com
}

\begin{abstract}
Abstrak:
Artikel ini akan mengeksplorasi bagaimana dinamika pengajaran serta pembelajaran di Era Digital. Studi ini memberikan kontribusi terhadap diskusi mengenai bagaimana seharusnya pendidikan memosisikan diri dalam perubahan zaman termasuk dalam menghadapi era digital. Melalui penelitian pustaka, peneliti menemukan beberapa aspek penting mengenai pengajaran dan pembelajaran di era digital yakni pembelajaran di era digital memiliki karakteristik yang berbeda dengan pembelajaran siswa pada masa sebelum ini, generasi di era ini adalah mereka yang berkarakter digital native. Siswa pada masa ini lahir, tumbuh dan besar bersentuhan langsung dengan dunia digital, sehingga arus informasi yang diperoleh akan berbeda dengan siswa sebelumnya. Oleh karenanya, guru sebagai mitra dalam belajar harus mampu mendesain kegiatan pembelajaran sehingga siswa memperoleh informasi lebih banyak dibanding waktu yang disediakan.
\end{abstract}

Kata Kunci: Pengajaran, Pembelajaran, Era Digital

\begin{abstract}
:
This article will explore how the dynamics of teaching and learning in the Digital Age. This study contributes to the discussion on how education should position itself in changing times, including in facing the digital age. Through library research, researchers found several important aspects of teaching and learning in the digital era, namely learning in the digital era has different characteristics from student learning in the past, the generation in this era are those who have digital native characters. Students at this time are born, grow and grow in direct contact with the digital world, so that the flow of information obtained will be different from previous students. Therefore, the teacher as a partner in learning must be able to design learning activities so that students get more information than the time provided.
\end{abstract}




\section{Keyword: Teaching, Learning, Digital Era}

\section{Pendahuluan}

Kemajuan merupakan suatu keniscayaan yang ingin dicapai semua bangsa, termasuk Indonesia. Bangsa Indonesia sudah melewati berbagai dinamika dan sudah kenyang manis pahitnya arus globalisasi. Gerakan reformasi yang telah digelorakan lebih dari 20 tahun telah banyak mempengaruhi berbagai sendi kehidupan di Indonesia. Dunia pendidikan khususnya menjadi salah satu instrumen yang terdampak oleh arus reformasi tersebut. Dunia pendidikan Indonesia pasca reformasi seolah seperti petani yang berganti tanaman, lahan garapannya tidak berubah, namun komuditi dan hasil yang diharapkan ingin lebih baik dan terus meningkat. Akan tetapi, asa manis yang digelorakan hingga kini belum maksimal.

Selama ini perubahan dan perbaikan yang digelorakan memang sudah berjalan dan berdampak pada perbaikan. Dilihat dari sisi kuantitas setiap tahun angka peserta didik dan institusi pendidikan terus meningkat. ${ }^{1}$ Namun dilihat dari sisi kualitas, perbaikan tersebut belumlah merata secara Nasional. Ketimpangan dan perbedaan potensi masing-masing daerah berpengaruh terhadap pelaksanaan aktivitas pendidikan itu sendiri. Inilah yang mengakibatkan kemajuan pendidikan di Indonesia solah berjalan lambat.

Disaat pemerintah sedang menggenjot sektor pendidikan agar dapat setara dengan pendidikan di negara maju tantangan kembali muncul. Dunia konvensional yang telah lama mendominasi dan menjadi budaya dunia, kini telah terkikis dan bukan mustahil peradaban konvensional akan lenyap. Perubahan besar ini berimplikasi pada pola pikir, aktivitas dan daya kreativitas masyarakat dunia secara umum. Dalam dunia pendidikan citra guru yang dulu dianggap paling dominan, perpengaruh dan multitalent oleh peserta didik lambat laun akan bergeser.

Pergeseran paradigma tersebut apakah lantas dimaknai secara pragmatis ataukah justru perlu disikapi secara arif. Bagi peserta didik boleh jadi guru yang hadir kini dengan "penampilan" masa lalu akan menjadikannya "malas" berinteraksi di sekolah. Sekolah dianggap tidak mampu mengakomudasi kebutuhan siswa. Jika ini yang terjadi maka sekolah terutama pendidik akan kehilangan ruhnya dimata peserta didik. Sebalinya, bagi pendidik yang mempu menampilkan sikap adaptif, momentum ini akan menjadi lecutan terbaik untuk meningkatkan pengetahuan, wawasan dan kecakapan "skill" siswa.

\footnotetext{
${ }^{1}$ Data Kemndiknas pertahun 2017/2018 jumlah peserta didik secara Nasion berjumlah 45,3 juta dengan rincian level SD 25, 49 juta, SMP 10, 13 juta, SMA 4,78 juta dan SMK 4,9 juta. Lihat website kemendiknas.
} 
Kemajuan di bidang teknologi informasi dan komunikasi memungkinkan rentang jarak antar pendidik dan peserta saling berkomunikasi melalui berbagai jejaring sosial. Komunikasi semacam ini tentu tidak terjadi pada 10 atau 20 tahun lalu. Perkembangan yang sedemikian pesat ini merubah arah pendidikan yang dulu hanya sebatas "education" menjadi "Edutaiment". Kedua pendekatan ini secara esensial tidaklah merubah hakikat proses kegiatan belajar mengajar di kelas namun dalam sisi yang lain terdapat perbedaan dalam perencanaan, strategi, teknik dan metode pengajarannnya. ${ }^{2}$

Perkembangan yang cepat di bidang teknologi, akan berdampak pada aspek kultural dan nilai-nilai suatu bangsa. Tekanan, kompetisi yang tajam di berbagai aspek kehidupan akan melahirkan generasi yang disiplin dan berbeda dengan generasi sebelumnya. Namun, di sisi lain, kompetisi yang ketat juga melahirkan generasi yang secara moral mengalami kemerosotan: konsumtif, boros dan memiliki jalan pintas bermental "instant”. Dengan kata lain, kemajuan teknologi dan pertumbuhan ekonomi yang terjadi, telah mengakibatkan kemerosotan moral di kalangan peserta didik juga masyarakat pada umumnya. Kemajuan kehidupan ekonomi yang terlalu menekankan pada upaya pemenuhan berbagai keinginan material, telah menyebabkan masyarakat menjadi "kaya dalam materi tetapi miskin dalam rohani".

Di dunia pendidikan, digitalisasi akan mendatangkan kemajuan yang sangat cepat, yakni munculnya beragam sumber belajar dan merebaknya media massa, khususnya internet dan media elektronik sebagai sumber ilmu dan pusat pendidikan. Dampaknya adalah guru/pendidik bukan satu-satunya sumber ilmu pengetahuan. Hasilnya, para siswa bisa menguasai pengetahuan yang belum dikuasai oleh guru. Oleh karena itu, tidak mengherankan pada era digital ini, wibawa guru khususnya dan orang tua pada umumnya di mata siswa merosot.

\section{Dinamika Pendidikan Glabal}

Pendidikan merupakan instrumen paling serius dan menjadi sorotan utama masingmasing negara. Kemajuan sebuah negara sering kali diukur dari tingkat kualitas pendidikanya. Semisal Filandia, negara ini dalam kurun 10 tahun terakhir mejadi perhatian global karena keberhasilannya merubah dan mentransformasikan konsep dan aplikasi pendidikannya.

\footnotetext{
2“Edutainment", yakni pendidikan yang menjadi hiburan dan hiburan yang merupakan pendidikan. Dengan "Edutainment" proses pendidikan akan semakin menarik dan menghasilkan lulusan yang semakin berkualitas. Lihat, M. Fadlillah, dkk, Edutaimen, Pendidikan Anak Usia Dini, (Jakarta: Kencana, 2016), hal. 5 .
} 
Finlandia bukan hanya menjadi yang terbaik di Eropa bahkan menjadi yang terbaik di dunia, bahkan sejak tahun 2000 Finlandia menjadi rool model PBB melalui badan UNICEF. ${ }^{3}$

Pendidikan yang diselenggarakan diberbagai dunia semula memiliki corak dan karakteristik yang berbeda-beda. Namun seiring perkembangan zaman, perbedaan tersebut semakin lama semakin terkikis. Paling tidak negara-negara berkembang saat ini berlombalomba mengejar ketertinggalan dengan negara maju. Adanya effort tersebut telah banyak mempengaruhi model dan pola pendidikan yang dikembangkan oleh negara-negara di seluruh dunia. Dinamika ini dapat dirasakan hingga ke Indonesia, indikasi tersebut dapat dilihat dari diterapkannya berbagai standar pelayanan dalam pendidikan di Indonesia, mulai standar ISO hingga standar-standar yang lainnya. ${ }^{4}$

Di Indonesia, perubahan tersebut dapat dilihat dengan adanya perubahan kurikulum yang diterapkan. Mulai dari kurikulum KBK, KTSP hingga kurikulum 13. Adanya perubahan pada kurikulum ini menunjukkan bahwa bangsa Indonesia selalu mengikuti dinamika pendidikan yang terus berkembang di dunia. Usaha ini dilakukan agar pendidikan di Indonesai mampu bersaing dengan Negara lain. Dengan adanya perubahan kurikulum dan kecanggihan teknologi diharapkan siswa Indonesia dapat dapat berprestasi ditingkat dunia.

Cita-cita mulia ini bukan berarti tanpa tantangan, setiap perubahan dan perbaikan yang dilakukan selalu muncul tantangan baru. Paling tidak saat ini ada beberapa tantangan yang dihadapi oleh Indonesia. Pertama terbatasnya akses pendidikan. Keterbatasan ini nyata dirasakan oleh masyarakat Indonesia, antara lain dengan jumlah ketersediaan institusi pendidikan dengan angkatan jumlah peserta didik. Akses yang terbatas ini, kemudian melahirkan sistem zonasi pada proses penerimaan peserta didik baru (PSB). Hingga kini sistem zonasi masih menjadi perdebatan oleh para ahli juga masyarakat yang terdampak langsung akibat sistem ini.

Tantangan kedua adalah jumlah guru yang belum merata, secara kuantitas ketersediaan tenaga pengajar di Indonesia belum tercukupi. Ketersediaan tenaga pengajar di kota-kota besar semisal Jakarta, Surabaya, Bandung, Jogjakarta dan kota-kota besar lainnya mungkin telah tercukupi, namun untuk daerah terluar dan terpencil jumlah tenaga pengajar belumlah sesuai yang diharapkan. Dari sisi kualitas tenaga pengajar jelas terdapat perbedaan, ini merupakan problem tersebasar yang saat ini dihadapi oleh dunia pendidikan Indonesia. ${ }^{5}$

\footnotetext{
${ }^{3}$ OECD, Development Assistent Peer Review: Finlandia 2012, hal. 41 hal. 11

${ }^{4}$ Suyanto, Dinamika Pendidikan Nasional dalam Percaturan Global, (Jakarta: Gramedia, 2006),

${ }^{5}$ Dede Rosyada, Madrasah Dan Profesionalitas Guru Dalam Arus Dinamika Pendidikan Islam di Indonesia, (Jakarta: Kencana, 2017), hal. 31
} 
Salah satu unsur dalam proses pendidikan adalah guru. Proses pendidikan di sekolah, guru memegang tugas ganda yaitu sebagai pengajar dan pendidik. Sebagai pengajar guru bertugas menuangkan sejumlah bahan pelajaran kepada peserta didik, sedangkan sebagai pendidik guru bertugas membimbing dan membina anak didik agar menjadi manusia yang berkhlak, cakap, aktif, kreatif, dan mandiri. Tanggung jawab guru sebagai tenaga profesional agar menjadi manusia susila yang cakap, aktif, kreatif, dan mandiri. Sikap guru terhadap pekerjaan merupakan keyakinan mengenai pekerjaan yang diembannya, disertai adanya perasaan tertentu, dan memberikan dasar kepada guru untuk respons dan berperilaku dalam cara tertentu sesuai pilihannya. Sikap guru terhadap pekerjaan mempengaruhi tindakan guru dalam menjalankan aktivitas kerjanya. Jika seorang guru memiliki sikap positif terhadap pekerjaannya, maka ia akan menjalankan fungsi dan kedudukannya sebagai tenaga pengajar dan pendidik di sekolah dengan penuh rasa tanggung jawab.

Adanya perbedaan kualiatas tenaga pengajar ini yang menyebabkan program pendidikan Nasional seolah berjalan lamban dan terkesan jalan ditempat. Idealnya, kemajuan pendidikan sebuah Negara haruslah ditunjang dengan ketersediaan institusi pendidikan dengan jumlah tenaga pendidik yang berkualitas. Ketersediaan tersebut juga harus ditunjang dengan kualitas yang baik, sehingga segela program yang telah disusun dalam program prioritas dapat dilaksanakan dengan baik. ${ }^{6}$

Di Indonesia, adanya perbedaan kualitas pendidikan ini bisa menimbulkan gejolak diberbagai bidang. Adanya perbedaan ini bisa menyebabkan perilaku separatisme, semisal yang terjadi di aceh, maluku dan papua. Daerah-daerah ini memiliki potensi sumber daya alam yang melimpah (natural resources) tetapi karena kualitas sumber daya manusia yang lemah mengakibatkan potensi alam tersebut dikelola dan dikuasai oleh pihak luar daerahnya. Kenyataan ini penting menjadi prioriatas dan perhatian bersama agar kualitas pendidikan yang meliputi institusi pendidikan, pendidik dan peserta didik dapat ditingkatkan sejalan dengan tantangan dan kebutuhan yang dihadapi. ${ }^{7}$

Keberhasilan suatu sekolah pada hakikatnya terletak pada efisiensi dan efektivitas peran seorang pendidik. Sedangkan Sekolah sebagai lembaga pendidikan bertugas menyelenggarakan proses pendidikan dan proses belajar mengajar dalam usaha untuk mencerdaskan kehidupan bangsa. Dalam hal ini kepala sekolah sebagai seseorang yang diberi tugas untuk memimpin

\footnotetext{
${ }^{6}$ Dede Rosyada, Madrasah Dan Profesionalitas Guru Dalam Arus Dinamika Pendidikan Islam di Indonesia,... hal. 31

${ }^{7}$ Abdulllah Idi, Dinamika Sosiologis Indonesia: Agama dan Pendidikan Dalam Perubahan Sosial,

(Yogyakarta: Lkis Pelangi Aksara, 2015), hal. 3
}

IQ (Ilmu Al-qur'an): Jurnal Pendidikan Islam | Volume 2 No. 012019 | 
sekolah, kepala sekolah bertanggung jawab atas tercapainya tujuan sekolah. Kepala sekolah diharapkan menjadi pemimpin dan inovator di sekolah. Oleh sebab itu, kualitas kepemimpinan kepala sekolah adalah signifikan bagi keberhasilan sekolah. ${ }^{8}$

Untuk menuju Indonesia yang semakin maju, yang ditandai dengan semakin berkembangnya sarana dan prasarana dibidang pendidikan juga dalam bidang-bidang yang lainnya perlu ditekan hal-hal yang dapat mengakibatkan konflik sosial. Konflik sosial perlu dilawan dan dikikis agar potensi moralitas manusia secara universal semakin terasah dan meningkat. Karena meningkatnya sebuah moralitas sebuah komunitas bukan saja menjadi tanggung jawab bersama akan tetapi ini merupakan seruan Tuhan. Dengan dinamika yang terus berkembang dikancah global diharapkan insan pendidik dan peserta didik di Indonesia akan semakin berkembang. ${ }^{9}$

\section{Pengajaran di Era Digital}

Dalam rentang 5 tahun terakhir ini, dunia pendidikan di Indonesia mengalami perubahan yang sangat pesat. Perubahan-perubahan yang muncul dalam pengajaran di kelas bukan saja datang dari internal guru sebagai pendidik karena adanya perubahan kurikulum dan standar yang diberlakukan oleh sekolah tetapi juga oleh faktor lainnya. Pengajaran yang dulu merupakan aktivitas yang didominasi oleh guru yang dianggap sebagai "sumber ilmu" kini perlu dikoreksi kembali. Perubahan inilah yang mengakibatkan adanya perubahan dalam alokasi waktu yang terus berkembang dengan cepat. Jika semula guru merencanakan pengajaran untuk tema tertentu dengan durasi tertentu, maka saat ini timing pengajaran perlu di realokasi lagi. ${ }^{10}$

Realokasi waktu pengajaran perlu mendapat perhatian besar, sebab siswa sebagai peserta didik saat ini tidak lagi pasif seperti saat era digital belum seperti saat ini. Kecenderungan siswa yang ingin selalu menjadi yang terbaik di kelas dalam segala mata pelajaran telah mengatarkan mereka untuk lebih gemar dan serius menggali informasi di luar ruang kelas. Akibatnya, siswa bisa jadi telah memperoleh informasi tentang tema yang akan dipelajari sebelum guru mengajarkan materi tersebut di ruang kelas. Perubahan yang terjadi kini memang tak terelakan lagi, oleh karenannya seorang pendidik harus memiliki paradigma

\footnotetext{
${ }^{8}$ Dede Rosyada, Madrasah Dan Profesionalitas Guru Dalam Arus Dinamika Pendidikan Islam di Indonesia,... hal. 34

${ }^{9}$ Abdulllah Idi, Dinamika Sosiologis Indonesia: Agama dan Pendidikan Dalam Perubahan Sosial,...hal. 4

${ }^{10}$ Budi Harsanto, Inovasi Pembelajaran di Era Digital: Menggunakan Google Sites dan Media Sosial, (Bandung: UNPAD Press, 2017), hal. 2
} 
baru dalam melakukan kegiatan pengajarannya di kelas dan di lingkungan sekolah. Dengan paradigma baru seorang pendidik akan lebih maksimal dalam memfasilitasi siswanya pada setiap kegiatan belajar mengajar.

Inovasi pengajaran perlu terus ditingkatkan untuk mencapai hasil belajar yang lebih berkualitas. Secara sosial saat ini interaksi guru dengan siswa di kelas seolah tanpa sekat, begitupun ketika berada di luar ruang kelas. Dulu jarak pendidik dan peserta didik seolah berjarak dan terasa semakin jauh jika berada di luar kelas, ledakan perubahan ini jika tidak diantisipasi dengan cermat akan melahirkan budaya belajar yang tak selaras. Saat ini peserta didik dari berbagai jenjang dapat menemukan apa saja yang ia mau dengan pendekatan $E$ learning. Model ini memiliki intensitas yang tak terbatas dan seolah dapat menembus dinding sekat ruang kelas dan materi pelajaran. ${ }^{11}$

Internet kini memiliki magnet yang begitu kuat, keberadaannya seolah mengalahkan pengaruh kehadiran guru di kelas. Bahkan jika dicermati, mulai marak dijumpai siswa yang bisa menikmati kelas selama akses internet tersedia, fenomena ini tentu berbeda dengan yang terjadi rentang 5 hingga 10 tahun lalu. Saat itu guru menjadi satu-satunya faktor yang paling ditunggu, inilah salah satu alasan mengapa model pengajaran di era digital kini perlu diantisipasi dengan melibatkan berbagai unsur, baik unsur internal sekolah juga eksternal sekolah. Adanya kemajuan teknologi seharusnya diimbangi dengan penguatan pada sektor lain, sehingga kemudahan yang dihasilkan akibat kemajuan teknologi tidak menggerus potensi siswa yang dikembangkan dengan pendekatan konvensional. Perbedaan yang mencolok ini perlu mendapatkan perhatian dan akses yang sama baiknya. Sehingga dengan dua pendekatan ini memiliki dampak yang signifikan terhadap pengetahuan dan penguasaan skill oleh peserta $\operatorname{didik.~}^{12}$

Meskipun demikian, peserta didik perlu dilatih untuk tidak bergantung sepenuhnya pada informasi yang ia gali sendiri. Seorang pendidik perlu memberikan penugasan yang membutuhkan interaksi antar siswa, dilatih menggunakan alat belajar secara manual, serta dilatih untuk mengenal pandangan/pemikiran yang berkembang di masyarakat sekitar. Penugasan-penugasan ini bukan untuk menghambat siswa dalam belajar, akan tetapi hal ini dimaksudkan sebagai penyeimbang agar siswa memiliki sikap teliti, sabar dan memiliki daya juang yang baik. Peserta didik saat ini memang bisa dikatakan sebagai native secara digital.

\footnotetext{
${ }^{11}$ Budi Harsanto, Inovasi Pembelajaran di Era Digital: Menggunakan Google Sites dan Media Sosial,...hal. 2

${ }^{12}$ Budi Harsanto, Inovasi Pembelajaran di Era Digital: Menggunakan Google Sites dan Media Sosial,...hal. 4
} 
Ketika dilahirkan dan mulai tumbuh besar, mereka sudah mengenal gadget. Jadi, sudah sewajarnya bila dunia pendidikan (sekolah) berubah mengikuti perkembangan zaman.

Menjadi pendidik di era digital membutuhkan usaha yang lebih keras jika dibandingkan dengan puluhan tahun ke belakang. Berkembangnya dunia digital terkadang membuat hubungan guru dan siswa tidak lagi seperti yang diharapkan. Jika dahulu siswa sangat menantikan guru sebagai wasilah datangnya ilmu dan wawasan baru, namun saat ini hal itu tidak terjadi lagi. Bukan hanya itu, siswa juga bisa menjadi bermasalah dengan adanya arus informasi yang tanpa diseleksi, sehingga apa yang diperoleh melalui informasi digital melebihi apa yang seharusnya ia pelajari. Sebagai contoh, media internet menjadi sebuah media yang benar-benar memberikan banyak keuntungan akan tetapi terdapat juga hal yang bisa membahayakan bagi anak. Berdasarkan riset yang dilakukan oleh Departemen Kehakiman Amerika Serikat yang membuktikan bahwa sekitar $70 \%$ anak mendapat kejadian buruk di internet. Bahkan 25\% dari mereka mendapatkan pelecehan seksual tanpa sepengetahuan orang tua mereka. Maka dari itu, anak harus diajarkan mengenai resiko dalam menggunakan internet. $^{13}$

Pelaksanakan pendidikan di Indonesia tentu tidak terlepas dari tujuan pendidikan di Indonesia, pendidikan Indonesia yang dimaksud ialah pendidikan yang dilakukan di Indonesia untuk kepentingan bangsa Indonesia. Pendidikan yang mengarah pada pendekatan efektif yang memungkinkan peserta didik untuk dapat belajar dengan mudah, menyenangkan dan dapat tercapai tujuan sesuai dengan yang diharapkan. Dengan demikian, pendidik dituntut untuk dapat meningkatkan keefektifan pembelajaran agar pembelajaran tersebut dapat berguna.

Hal lain yang perlu ditingkatkan oleh seorang pendidik adalah efisiensi, waktu yang digunakan dalam proses pengajaran, mutu pegajar dan hal lain yang menyebabkan kurang efisiennya proses pengajaran di kelas dan di lingkungan sekolah. Yang terlihat sekarang, kurangnya mutu pengajar disebabkan oleh pengajar yang mengajar tidak pada kompetensinya. Misalnya, pengajar X mempunyai dasar pendidikan di bidang matematika, namun di mengajarkan olah raga, yang sebenarnya bukan kompetensinya. Hal-tersebut benar-benar terjadi jika melihat kondisi pendidikan di lapangan yang sebanarnya. Hal lain adalah pendidik tidak dapat mengomunikasikan bahan pengajaran dengan baik, sehingga mudah dimengerti dan membuat tertarik peserta didik. Sistem pendidikan yang baik juga berperan penting dalam meningkatkan efisiensi pendidikan di Indonesia. ${ }^{14}$

${ }^{13} \mathrm{https://blogs.itb.ac.id/feeds/mendidik-anak-millenial-eradigital,} \mathrm{diakses} \mathrm{pada} 5$ juli 2019

${ }^{14}$ Ani Ismayani, Cara Mudah Membuat Aplikasi Pengajaran Berbasis Android dengan Thunkble, (Jakarta: PT. Elex Media Komputindo, 2018), hal. 2 
Peserta didik di era industri 4.0 memiliki karakteristik yang sangat berbeda. Era digital akan melahirkan generasi digital netive yang berarti generasi yang lahir, tumbuh, besar dan berinteraksi dengan berbagai macam media digital. Kondisi tersebut akan berdapak langsung pada psikologis yang mempengaruhi peta kognitifnya. Kebutuhan, perubahan dan kebiasaan siswa akan cenderung mengikuti hal-hal yang ia saksikan melalui media yang paling sering ia lihat dan mereka gunakan. Jika mekanisme ini tidak diantisipasi dengan tepat disisi lain akan melahirkan generasi yang pandai berbohong, prilaku sosial menyimpang, prestasi sekolah menurun dan bahkan pada perilaku yang merugikan dirinya sendiri juga orang lain. ${ }^{15}$

\section{Pembelajaran Di Era Digital}

Perlu mendapat perhatian bahwa pembelajaran merupakan aktivitas yang berbeda dengan pengajaran, jika pengejaran adalah aktivitas yang dipelopori dan didoniminasi oleh seorang pendidik, maka pembelajaran adalah aktivitas yang disajikan oleh pendidik dan kemudian diarahkan sepenuhnya untuk dimanfaatkan oleh peserta didik dalam menggali, mengelola dan mengembagkan wawasan dan pengetahuan baru. Bagi pendidik, fokus pada frame work ini perlu diperhatikan agar tidak terjadi disorientasi pada setiap aktivitas belajar di kelas yang akan dilaksanakan bersama. Kualitas pembelajaran bisa disajikan dengan adanya kerja sama yang konstruktif antara guru sebagai pendidik dan siswa sebagai peserta didik.

Bagi seorang pendidik, kemampuan menyajikan materi baru perlu dimiliki dengan sangat baik, jika tidak maka peserta didik akan cederung lebih cepat bosan karena materi yang ditampilkan tidak mimiliki nilai kebaruan. Inilah yang membedakan cara belajar siswa milineal dengan cara belajar siswa dahulu. Materi yang tersusun dalam kurikulum secara ensensial memang tidak banyak mengalami perubahan, akan tetapi dalam kasus dan contoh yang ditampilkan di ruang belajar harus aplikatif dan memiliki nilai kebaruan. Nuansa ini penting diciptakan agar siswa lebih cepat menangkap dan memahami tema yang sedang dipelajari. Perlu diingat bahwa gaya belajar siswa kini cenderung berpola convergen, siswa memiliki kencederungan untuk menggali informasi secara acak dan jauh di luar apa yang ia inginkan. ${ }^{16}$

Dari berbagai instrumen yang ada, adanya persamaan kurikulum dalam berbagai tingkatan pendidikan di Indonesia yang diberlakukan secara Nasional mestinya dapat dimanfaatkan oleh seorang pendidik agar dapat mengoptimalkan kemampuan peserta didik.

\footnotetext{
${ }^{15}$ Ida Widianingsih, Strategi dan Inovasi Pembelajara Bahasa di Era Revolusi Industri 4.0, (Ponorogo, Uwais Inspirasi Indonesia, 2019), hal 10

${ }^{16}$ Winastwan Gora dan Sunarto, PAKEMATIK: Setrategi Pembelajaran Berbasis TIK, (Jakarta: PT. Elex Media Komputindo, 2018), hal.
} 
Dalam proses pembelajaran siswalah yang menjadi fokus kegiatan selama proses belajar mengajar berlangsung. Karenanya desin kurikulum yang ada harus dapat diterjemahkan oleh seorang pendidik pada tataran yang praktis, mudah, measureble dan bersifat elastis dan dialektis. Jika kurikulum bersifat kaku akan membatasi ruang "gerak" siswa dalam mengembangkan potensi kognitif, spikomotor juga potensi afeksinya. ${ }^{17}$ Siswa pada posisi ini menjadi subjek yang diarahkan untuk menemukan dan memahami materi pelajaran, dengan adanya pendekatan ini siswa tidak lagi harus menunggu informasi dari guru, melainkan siswa memiliki ruang untuk menemukan wawasan baru dengan desain dan materi yang telah dirancang sebelumnya oleh guru.

Selanjutnya, pembiasaan belajar secara mandiri perlu dikembangkan dan diinternalisasikan pada siswa. Dengan segala potensi dan daya dukung yang dimiliki oleh siswa kemandirian belajar perlu didukung dan diarahkan oleh seorang pendidik. Kemandirian dalam belajar bukan berarti melepaskan tanggung jawab pendidik dalam membimbing dan memfasilitasi peserta didik dalam belajar, akan tetapi hal ini dimaksudkan untuk menstimulasi tanggung jawab, kreativitas dan membangun kemampuan berfikir logis dan kritis. Dengan pendekatan seperti ini, aktivitas belajar siswa di era digital akan menemukan satu pola yang terstruktur dan dapat berkesinambungan dengan alur kurikulum yang telah ditentukan. ${ }^{18}$

Perubahan paradigma dalam proses KBM harus berubah, jika dahulu kebiasan belajar mengajar karena adanya guru yang mengajar di kelas saat ini harus bergeser bahwa kegiatan belajar mengajar adalah untuk memfasilitasi tumbuh kembangnya potensi siswa. Ini akan memiliki implikasi yang berbeda, jika pengajaran hanya didominasi oleh guru maka target dan strategi hanya sebatas dengan kemampuan yang dimiliki oleh guru. Akan tetapi jika proses KBM difokuskan pada kegiatan pembelajaran, maka seorang guru akan bekerja keras untuk menemukan berbagai metode dan teknik agar proses KBM dapat dinikmati oleh seluruh siswa. Dengan perubahan pendekatan dan strategi yang digunakan, maka pendekatan pembelajaran akan melahirkan peserta didik yang terbiasa berfikir konstruktif, kritis dan dapat menemukan jawaban atas perseoalan yang dijumpai selama proses KBM berlangsung. ${ }^{19}$

Kemajuan teknologi dalam pembelajaran idealnya dapat dimanfatkan oleh pendidik dalam meningkatkan potensi peserta didik, bukan sebaliknya. Kemampuan menggunakan teknologi informasi antara siswa milenial dengan masa sebelumnya tentu berbeda. Sehingga dengan bekal pengusaan teknologi informasi ini dapat dijadikan sebagai nilai tambah dalam

\footnotetext{
${ }^{17}$ Yusuf Hadi Miarso, Menyemai Benih Teknologi Pendidikan (Jakarta: Kencana, 2016), hal. 4

${ }^{18}$ Yusuf Hadi Miarso, Menyemai Benih Teknologi Pendidikan,... hal. 4

${ }^{19}$ Mohammad Khozin, Santri Milenial, (Jakarta: Bhuana Ilmu Populer, 2018), hal. 4
} 
menunjang kegiatan belajar siswa di kelas. Jika pendekatan ini dapat dimentenence dengan baik maka siklus kegiatan belajar mengajar akan berjalan lebih cepat dengan variasi kegiatan yang lebih variatif. Bukan sebaliknya, karena keterbatasan seorang pendidik dalam menggunakan teknologi informasi lalu membatasi gerak siswa dalam menggunkannya. ${ }^{20}$

Pendekatan pembelajaran di era digital seharusnya memberikan ruang bagi siswa untuk belajar seketika (immediacy of learning). Hal ini dapat mengurangi jurang pemisah antara di dalam dan di luar sekolah. Perlu diperhatikan gaya belajar siswa era digital bukan saja meneliti dan mengamati objek yang hanya ada di ruang kelas, akan tetapi mereka juga terbiasa menyimpan dan mengumpulkan berbagai informasi yang diperoleh dari ruang-ruang selain ruang kelas. Selain itu, siswa di era milenial juga terbiasa mengungkapkan pengetahuannya secara langsung tanpa perlu dikonsep atau dipersiapkan terlebih dahulu seperti siswa-siswa pada masa sebelum ini. Perpaduan kemampuan baru ini tentu membutuhkan konsep pendekatan yang tepat agar keberadaan siswa di kelas dianggap penting sehingga siswa memiliki semangat dan spirit tinggi untuk menyelesaikan tugas belajarnya dengan lebih baik. ${ }^{21}$

Dengan strategi pembelajaran yang tepat, memungkinkan penyajian materi pelajaran lebih luas. Hal ini karena adanya link and mach antar guru sebagai pendidik dan siswa sebagai peserta didik, sehingga dengan ketepatan pola yang dikembangkan potensi siswa sebagai peserta didik dapat melesat bahkan dapat menembus ruang pengetahuan yang langka. Dengan keleluasaan model pembelajaran yang dikembangkan oleh guru kepada siswanya akan dapat menembus ruang-ruang geografi keilmuan yang semula hanya dapat ditemui dan diperoleh dengan mendatanginya secara langsung, namun dengan pendekatan semacam ini, ruang geografi keilmuan akan dapat ditembus tampa mendatanginya secara langsung. Sekali lagi model pengajaran dan pembelajaran memiliki fokus dan lokus yang berbeda, sehingga penting bagi guru sebgai pendidik untuk mengambil peran dan memanfaatkannya dengan cermat. ${ }^{22}$

\section{Kesimpulan}

Telah dikumukakan dengan mendetail bahwa pendidikan menjadi salah satu barometer kemajuan sebuah Negara, dengan alasan inilah sebuah Negara akan melakukan berbagai kebijakan agar pendidikannya semakin maju ditengah arus globalisasi yang terus bergerak

\footnotetext{
${ }^{20}$ Dhitta Putri Saraswati, Mendidik Pemenang Bukan Pencundang, (Yogyakarta: PT. Bentang Pustaka, 2016), hal. 14

${ }^{21}$ Dewi Salma Prawiradilaga, dkk., Mozaik Teknologi Pendidikan: E-Learning, (Jakarta: Kencana, 2013), hal 10

${ }^{22}$ Dhitta Putri Saraswati, Mendidik Pemenang Bukan Pencundang,...hal. 14
} 
dengan cepat. Sebab dengan bekal pendidikan yang maju sebuah Negara akan memperoleh kemajuan dalam berbagai bidang, semisal bidang teknologi, ekonomi, sosial juga kebudayaannya.

Dalam konteks dinamika pembelajaran dan pengejaran di era digital yang telah diulas di atas, dapat ditarik keseimpulan sebagai berikut:

Dinamika dalam dunia pendidikan akan terus terjadi seiring dengan perubahan itu sendiri. Karenanya unsur ini bergerak dengan dinamis, sehingga faktor eksternal juga faktor internal yang ditimbulkannya harus diimbangi dengan langkah yang tepat dan akomodatif. Berubahan pola pendidikan dunia dan perubahan kurikulum, idealnya dijadikan sebagai spirit untuk membangkitkan semngat juang dalam memajukan pendidikan dan bukan malah sebaliknya, adanya perubahan tersebut malah menyurutkan daya juang seorang pendidik.

Dalam konteks pengajaran, guru yang hadir di era digital harus dapat mengikuti ritme dan irama yang berkembang di masa ini, seorang pendidik tidak boleh statis dengan statusnya yang dulu, sehingga guru dapat mengikuti perkembangan secara dinamis serta dapat memanfaatkan kemajuan teknologi informasi sebagai salah satu media dalam menjalankan tugasnya sebagai seorang pengajar. Kehadiran guru di kelas dengan kemajuan teknologi harus dapat dimanfaatkan sebagai salah satu sumber belajar yang memiliki nilai kebaruan, sehingga akses informasi yang diberikan oleh guru sebagai pendidik dan siswa sebagai peserta didik bisa lebih banyak, variatif dan konstruktif.

Pembelajaran di era digital memiliki karakteristik yang berbeda dengan pembelajaran siswa pada masa sebelum ini, generasi di era ini adalah meraka yang berkakter digital netive. Siswa pada masa ini lahir, tumbuh dan besar bersentuhan langsung dengan dunia digital, sehingga arus informasi yang diperoleh akan berbeda dengan siswa sebelumnya. Oleh karenanya, guru sebagai mitra dalam belajar hatrus mampu mendesain kegiatan pembelajaran sehingga siswa memperoleh informasi lebih banyak dibanding waktu yang disediakan.

Demikian akhir dari tulisan ini, semoga dapat menginspirasi dan dapat dimanfaatkan sebagai rujukan dalam menjalankan tugas sebagai seorang pendidik, baik saat merencanakan, melakukan hingga mengevaluasi proses belajar mengajar secara keseluruhan. 


\section{Daftar Purtaka}

Abdulllah Idi, Dinamika Sosiologis Indonesia: Agama dan Pendidikan Dalam Perubahan Sosial, (Yogyakarta: Lkis Pelangi Aksara, 2015).

Ani Ismayani, Cara Mudah Membuat Aplikasi Pengajaran Berbasis Android dengan Thunkble, (Jakarta: PT. Elex Media Komputindo, 2018).

Budi Harsanto, Inovasi Pembelajaran di Era Digital: Menggunakan Google Sites dan Media Sosial, (Bandung: UNPAD Press, 2017).

Dede Rosyada, Madrasah Dan Profesionalitas Guru Dalam Arus Dinamika Pendidikan Islam di Indonesia, (Jakarta: Kencana, 2017).

Ida Widianingsih, Strategi dan Inovasi Pembelajara Bahasa di Era Revolusi Industri 4.0, (Ponorogo, Uwais Inspirasi Indonesia, 2019). M. Fadlillah, dkk, Edutaimen, Pendidikan Anak Usia Dini, (Jakarta: Kencana, 2016).

OECD, Development Assistent Peer Review: Finlandia 2012.

Suyanto, Dinamika Pendidikan Nasional dalam Percaturan Global, (Jakarta: Gramedia, 2006,).

Winastwan Gora dan Sunarto, PAKEMATIK: Setrategi Pembelajaran Berbasis TIK, (Jakarta: PT. Elex Media Komputindo, 2018).

Yusuf Hadi Miarso, Menyemai Benih Teknologi Pendidikan, (Jakarta: Kencana, 2016). https://blogs.itb.ac.id/feeds/mendidik-anak-millenial-eradigital. https://www.kemdikbud.go.id 